\title{
The Inoculation of Probiotics In Vivo Is a Challenge: Strategies to Improve Their Survival, to Avoid Unpleasant Changes, or to Enhance Their Performances in Beverages
}

\author{
Barbara Speranza, Daniela Campaniello, Leonardo Petruzzi, Clelia Altieri, Milena Sinigaglia, \\ Antonio Bevilacqua * (D) and Maria Rosaria Corbo *(D) \\ Department of the Science of Agriculture, Food and Environment (SAFE), University of Foggia, Via Napoli 725 , \\ 71122 Foggia, Italy; barbara.speranza@unifg.it (B.S.); daniela.campaniello@unifg.it (D.C.); \\ leonardo.petruzzi@unifg.it (L.P.); clelia.altieri@unifg.it (C.A.); milena.sinigaglia@unifg.it (M.S.) \\ * Correspondence: antonio.bevilacqua@unifg.it (A.B.); mariarosaria.corbo@unifg.it (M.R.C.)
}

Received: 22 January 2020; Accepted: 16 March 2020; Published: 27 March 2020

\begin{abstract}
The inoculation of probiotics in beverages (probiotication) requires special technologies, as probiotic microorganisms can experience stress during food processing (acid, cold, drying, starvation, oxidative, and osmotic stresses) and gastrointestinal transit. Survival to harsh conditions is an essential prerequisite for probiotic bacteria before reaching the target site where they can exert their health promoting effects, but several probiotics show a poor resistance to technological processes, limiting their use to a restricted number of food products. Therefore, this paper offers a short overview of the ways to improve bacterial resistance: by inducing a phenotypic modification (adaptation) or by surrounding bacteria through a physical protection (microencapsulation). A second topic briefly addressed is genetic manipulation, while the last section addresses the control of metabolism by attenuation through physical treatments to design new kinds of food.
\end{abstract}

Keywords: probiotic; beverages; stress; attenuation; phenotypic changes; manipulation

\section{Introduction}

Beverages containing viable cells of probiotics are generally milk-based products, for instance, yogurts [1]. However, in the last decade, the demand for nondairy probiotics has increased for a wide variety of issues (increasing incidence of lactose intolerance and/or worry about the high cholesterol content of some products, new lifestyles etc.).

Many authors have addressed the design/preparation of functional beverages and foods, for example, fruit juices (pomegranate, pineapple, coconut, blueberry etc.) [2,3]; whey-based beverages [4]; vegetable juices [5]; cereals and soy [6,7]; unconventional milk [8]; ice-cream [9]; cereal-based beverages; and traditional drinks based on cereal beverages, such as borş, ogi, akamu, gowe, bushera, togwa, and mageu, among others $[10,11]$. The importance of this tendency can be inferred by the use of a new word, i.e., "probiotication" deriving from probiotic and inoculation/enrichment [12].

The inoculation of probiotics in nondairy beverages (cereal, fruit, and vegetable juices) has a key benefit: the possibility of combining probiotic microorganisms with prebiotics or prebiotic-like compounds, thus producing synbiotics [13]. Considering the fact that a probiotic is essentially active in the small and large intestines, and the effect of a prebiotic is observed mainly in the large intestine, the combination of the two may have a synergistic effect [14]. There are two possible modes of action of synbiotics: (i) the improved viability of probiotic microorganisms; ii) the provision of specific health effects $[13,15]$. 
Other reported health benefits are: (i) increased Lactobacillus and Bifidobacterium genera count and maintenance of intestinal microbiota balance; (ii) enhanced hepatic function in patients with cirrhosis; (iii) improved immunomodulative abilities; (iv) prevention of bacterial translocation and reduced incidence of post-operative nosocomial infections [16].

Chaudary [12] proposed two ways of probiotic enrichment: fermentation or inoculation. However, apart from technological flowsheet, the greatest challenge for probiotic bacteria is enduring stresses encountered during food processing and gastrointestinal transit.

The fundamental characteristic routinely evaluated in potential probiotic strains is their limited viability loss during gastrointestinal transit, but to date, there is no evidence on whether probiotics, in addition to viability, still also maintain their beneficial properties [17]. Their performance, in fact, can be significantly affected by exposure to certain kinds of stress (acid, cold, drying, starvation, oxidative, and osmotic stresses), which can influence the physiological status and functional properties of bacterial cells [18]. Table 1 provides an overview of the most important stresses encountered by probiotics.

Table 1. Stresses encountered by food-grade microorganisms during food production and storage [19-21].

\begin{tabular}{|c|c|}
\hline Stress & Description \\
\hline Acid & $\begin{array}{l}\text { Acid-stress could be self-imposed (production of lactic } \\
\text { acid or other acids because of fermentation) or } \\
\text { environmental stress (juices, dairy beverages, } \\
\text { gastrointestinal tract, etc.). Acidification of cytosol is } \\
\text { genotoxic and causes the denaturation of proteins, with } \\
\text { a deleterious effect on overall metabolism (energy } \\
\text { depletion and death). }\end{array}$ \\
\hline Bile & $\begin{array}{l}\text { Bile salts can cause disruption of membranes, DNA } \\
\text { damage, misfolding and/or denaturation of proteins, } \\
\text { and chelation of iron and calcium. }\end{array}$ \\
\hline Oxidative & $\begin{array}{l}\text { Lactic acid bacteria are sensitive to aerobic } \\
\text { environments; moreover, some strains can produce } \\
\text { ROS (reactive oxygen species) by themselves. }\end{array}$ \\
\hline Cold and chilled & $\begin{array}{l}\text { Starters and probiotic cultures are stored in a frozen or } \\
\text { freeze-dried form; in addition, storage generally occurs } \\
\text { under refrigerated conditions. Viability decreases } \\
\text { during storage because of certain factors (glass } \\
\text { transition temperature, light, relative humidity, etc.). }\end{array}$ \\
\hline Heat shock & $\begin{array}{l}\text { Starter cultures could be exposed to reheating or high } \\
\text { temperatures, mainly in dairy products. }\end{array}$ \\
\hline Osmotic & $\mathrm{NaCl}$ is added to inhibit spoilers and pathogens. \\
\hline Starvation & $\begin{array}{l}\text { Starvation could occur as a side-effect of stress (for } \\
\text { example, auto-acidification interferes with membrane } \\
\text { carriers). }\end{array}$ \\
\hline High-pressure/Homogenization/Ultrasound & $\begin{array}{l}\text { There are several alternative approaches to thermal } \\
\text { treatments; the most used one is HHP (high hydrostatic } \\
\text { pressure). It can induce physiological changes, changes } \\
\text { in gene expression and protein translation, and cell } \\
\text { damage. } \\
\text { Injuries to cells also occur in the case of } \\
\text { homogenization, while ultrasound can cause the } \\
\text { formation of pores on the membranes }\end{array}$ \\
\hline Ethanol & $\begin{array}{l}\text { Ethanol stress is important for yeast and lactic acid } \\
\text { bacteria involved in the production of } \\
\text { alcohol-containing beverages. }\end{array}$ \\
\hline Antimicrobial compounds & $\begin{array}{l}\text { Several beverages contain natural antimicrobials, such } \\
\text { as phenols in juices or lysozyme and lactoferrin in } \\
\text { dairy products. They act on different targets } \\
\text { (membranes, cell wall, etc.) in cells and may cause } \\
\text { lethal or sublethal injuries. }\end{array}$ \\
\hline
\end{tabular}


Survival in harsh conditions is an essential prerequisite for probiotic bacteria before reaching the target site where they can exert their health-promoting effects [22], but several probiotics show a poor resistance to technological processes, limiting their use to a restricted number of beverages.

Therefore, this paper offers a short overview of the most important approaches to counteract this challenge; namely, the first two sections address the issue of improving bacteria resistance by inducing a phenotypic modification (adaptation) or surrounding bacteria through a physical protection (microencapsulation)

A second challenge briefly addressed in this paper is the genetic manipulation, while the last section addresses another kind of problem: the need of controlling the metabolism of probiotics in several beverages in order to reduce or eliminate unfavorable changes in sensory scores (attenuation) or to improve their performances (modulation) through physical treatments to design new kinds of food (Figure 1).

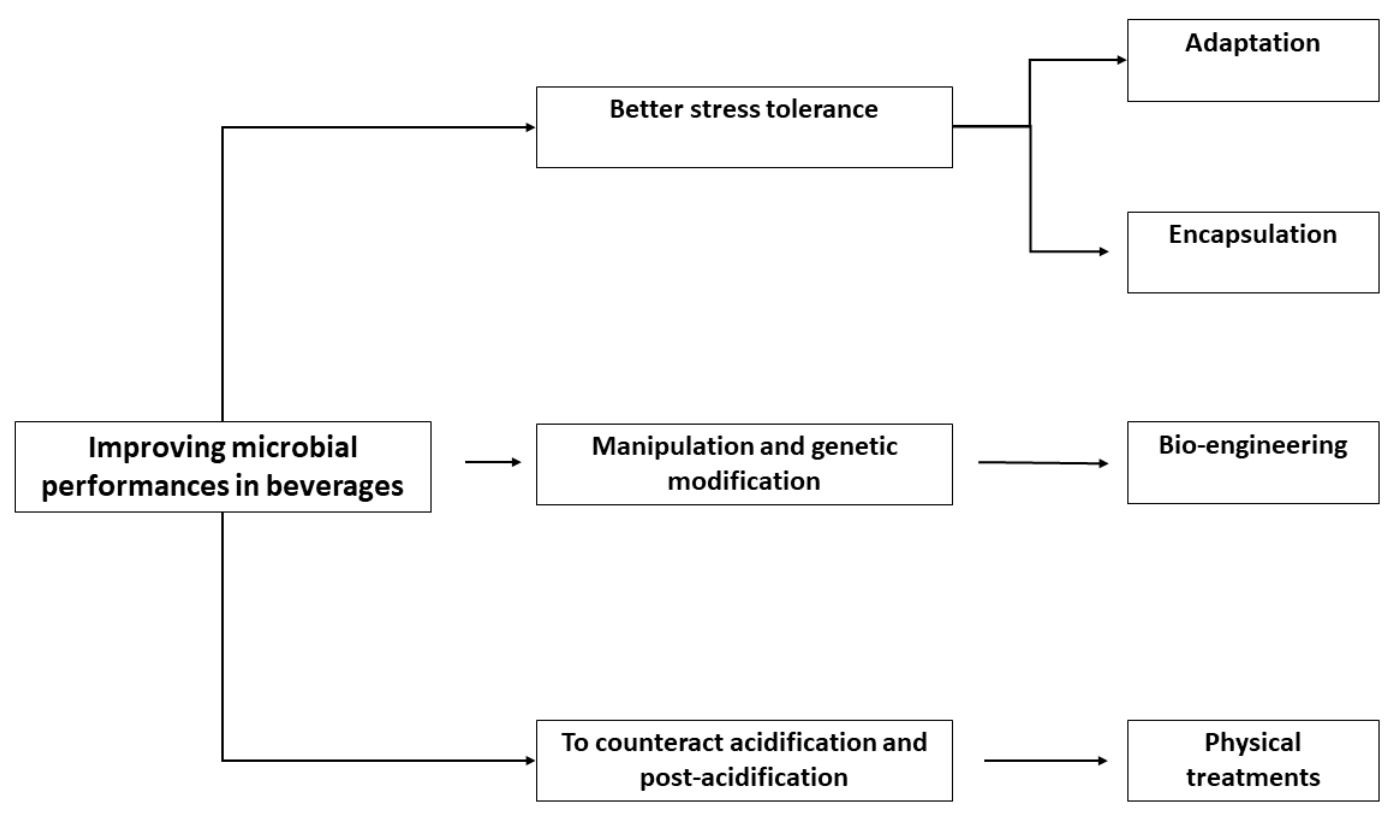

Figure 1. Strategies to improve the performances of probiotics in beverages.

\section{Adaptive Evolution}

Phenotyping is one of the most commonly used methods to modify the properties of probiotics and food-grade microorganisms; this approach has been referred to by many authors as "adaptive evolution" or "pre-adaptation or cross-protection" and has some applications for the inoculation of probiotics in fruit-juices $[19,21,23]$.

Bacterial cells possess a multitude of defense mechanisms, such as chaperones to assist folding of misfolded proteins, proteases which degrade proteins which are irreversibly damaged, transport systems, catalases, and superoxide dismutases to counteract ROS, as well as proton pumps, decarboxylases, and transporters to combat decreases in intracellular $\mathrm{pH}[19,21,23]$. Isolation and identification of naturally-tolerant strains can ensure robustness during processing and storage (thermal treatments, freeze-drying, chilled or cold storage, presence of antimicrobial compounds such as phenols, etc.), and gastrointestinal transit. Alternatively, exploiting the inherent probiotic stress response to improve tolerance capacities of existing probiotic strains could make them amenable to large-scale production and storage [21].

Pre-adaptation or adaptive evolution or "habituation" [19] consists in treating a microorganism to a sublethal stress for a limited time; this treatment would act on strain resistance when exposed to a higher level of stress or to another stress. The mechanism behind pre-adaptation is not well understood; however, it is known that bacteria have two ways to counteract stresses: cross-protection and GSR 
(general stress response) [23]. Cross-protection relies on the principle that interrelated responses are generated by different stress conditions; different stimuli (heat, oxygen, low $\mathrm{pH}$, etc.) might produce similar responses. GSR is the acquired resistance to some conditions when a population enters the stationary phase [23].

Adaptive responses are generally based on epigenetics mechanisms, because regrowth of adapted cells under optimal conditions reduces or eliminates any resistance phenotype after a few generations [19]. However, stress-induced mutations could also occur, and thus, cells exposed to some stresses enter a hypermutable state [19]; some evidence of this phenomenon has been found for lactic acid bacteria [24,25].

The most commonly used approach for stress adaptation is the modification of the growth medium and/or incubation conditions with different strategies:

(a) $\mathbf{p H}$ modification to trigger acid adaptation [21,26-28]: Probiotics are cultured in media adjusted to suboptimal $\mathrm{pH}$ (4.5-5.5) for several passages before inoculation in acid matrix (for example, fruit juices);

(b) Osmoadaptation [29,30]: Microorganisms are grown in hyperosmotic media (for example, hyperconcentrated sweet whey) to trigger adaptation to drying;

(c) Media supplementation with sugars (mannose, trehalose, sucrose) [31,32] to improve viability during freeze-drying;

(d) Media supplementation with protective compounds (arginine, Tween 80, aspartate, gluthatione) $[19,21]$ to improve acid resistance;

(e) Media supplementation with prebiotics [33,34] generally increases viability throughout storage;

(f) Starvation [28] for a general increase of viability during storage: Probiotics are cultured in media with a few nutrients (amino acids and/or sugar) before inoculation in food. This practice could increase viability during refrigerated storage;

(g) Cold-adaptation [35]: Probiotics and/or starter strains are cultured at suboptimal temperatures $\left(15-20^{\circ} \mathrm{C}\right)$, thus increasing their technological performances in food;

(h) Media supplementation with phenols (for example, vanillic acid) to improve strain viability in juices [26];

(i) Strain culturing in presence of increasing amount of the final food matrix [26]: Probiotics could be cultured in the presence of increasing amounts of juices (from $10 \%$ to $50 \%$ ), thus increasing their viability in the product.

Another kind of pretreatment is heat adaptation based on microbial exposure to sublethal temperatures (for example, $52^{\circ} \mathrm{C}$ for $15 \mathrm{~min}$ ) [36]; this pretreatment can increase resistance to low or alkaline pHs, ROS, ethanol, spray-drying, etc.

There are different molecular mechanisms beyond adaptation and bacterial resistance; Table 2 shows the most important phenomena.

There are several examples of application of cross-adaptation to improve the performances of probiotics mainly in juices. For example, Perricone et al. [26] addressed the issue of viability of Lactobacillus reuteri in juices produced from red fruits; they used two different kinds of protocols: strain cultivation in lab media acidified to $\mathrm{pH} 5.0$ or containing a phenolic compound (vanillic acid) or a sequential protocol based on strain growing in presence of increasing amount of red-juices. Thus, they increased the viability of the probiotic by 9-11 days.

A different approach was proposed by Shah et al. [37] to protect Lactobacillus rhamnosus, Lactobacillus paracasei and Bifidobacterium lactis from oxygen; they supplemented juices with antioxidants (vitamin C, grape extract, and green tea extract); after 6 weeks, the probiotic was at 4-6 log cfu/mL, while in the control, it was below the detection limit.

The supplementation of threalose, combined with a sublethal homogenization at 25-150 MPa, improved the viability of $L b$. reuteri in clementine juice and throughout the transit into the gut and its antimicrobial activity against Helicobacter pylori [38]. 
Da Costa et al. [39] also proposed supplementation with certain active ingredients (ascorbic acid and oligofructose); the effect was not protective of the probiotic ( $\mathrm{Lb}$. paracasei), but a positive modulation of color and turbidity throughout refrigerated storage at $4{ }^{\circ} \mathrm{C}$.

Table 2. Stress adaptation triggered by pretreatments (references and data reported in Gaucher et al. [21]).

\begin{tabular}{|c|c|c|}
\hline Mechanisms & Description & Involved In \\
\hline Compatible solutes & $\begin{array}{l}\text { Accumulation of trehalose, glycerol, and } \\
\text { amino acids (proline, glutamate, lysine, } \\
\text { arginine, glycine betaine) }\end{array}$ & $\begin{array}{l}\text { Osmotic adaptation, acid-tolerance, } \\
\text { cold and oxidative stresses }\end{array}$ \\
\hline Energy storage compounds & Accumulation of phosphates and glycogen & Osmotic and oxidative stresses \\
\hline ATPase & $\begin{array}{l}\text { Regulation of ATPase activity and } \\
\text { overproduction of ATP }\end{array}$ & Acid stress \\
\hline Substrate conversion & $\begin{array}{l}\text { Redirection of pyruvate } \\
\text { Increase of the activity of arginine } \\
\text { deaminase system } \\
\text { Overproduction of enzymes involved in } \\
\text { catabolism and energy production }\end{array}$ & Acid, cold, osmotic and heat stresses \\
\hline Membrane fluidity & $\begin{array}{l}\text { Change in the ratio unsaturated/saturated } \\
\text { fatty acids }\end{array}$ & Cold, heat, bile and acid stresses \\
\hline Cell wall & $\begin{array}{l}\text { Increase in hydrophobicity and changes in } \\
\text { lipotheicoic acids }\end{array}$ & Osmotic stress \\
\hline S-layers & Overproduction of S-layers & Bile, acid, heat and salt stresses \\
\hline EPS (esopolysaccharides) & Improved EPS production & Acid stress \\
\hline $\begin{array}{l}\text { Molecular chaperones and stress } \\
\text { response proteases }\end{array}$ & $\begin{array}{l}\text { Upregulation/production of: } \\
\text { GroEL and GroES (bacterial chaperonin } \\
\text { involved in protein folding) } \\
\text { HSP (heat shock proteins) } \\
\text { DnaK (DNA replication) } \\
\text { CSP (cold shock proteins) }\end{array}$ & Acid stress \\
\hline
\end{tabular}

\section{Encapsulation}

Microencapsulation has recently been suggested as a convenient tool to improve probiotics' survival not only under gastrointestinal conditions, but also in functional foods such as milk derivatives or novel functional beverages. As is known, microcapsules are generally formed to include sensible compounds (solid, liquid or gaseous) within protective matrices (food-grade biopolymers) by entrapping or surrounding them [40]. An optimal encapsulation process can provide protection against unfavorable environmental conditions, but allowing a controlled release of the encapsulated core and ensuring all main diffusion processes (oxygen and nutrients effluxes, but also waste product expulsion) [40].

Bacterial cells, namely probiotics, have also been successfully microencapsulated, and their recovered higher viability has attracted a great amount of attention from researchers during the last decade [41-46]. Encapsulation of probiotics not only provides higher cell loads [47], but also a strong protection of cells against physicochemical changes, such as $\mathrm{pH}$, temperature, bile salts, etc. [48-52]. Some studies have also observed that encapsulated probiotics show higher productivity and efficiency [53] and better fermentation processes [54].

In literature, different methods are suggested for the encapsulation of probiotics, such as spray drying, extrusion, emulsion or phase separation, freeze drying, ionotropic gelation [55], but vibrational extrusion is suggested as the better technique in term of easiness, low cost, higher cell recovery $(80-95 \%)$, and effectiveness in protection under stress conditions $[47,56]$. During extrusion, capsules are obtained by simply dropping an aqueous solution of probiotics into a gelling bath: The beads have sizes and shapes in the range of 2-5 $\mathrm{mm}$ and depend on the diameter of the needle used [57].

With regard to entrapping materials, polysaccharides (alginate, plant/microbial gums, chitosan, starch, k-carrageenan, cellulose acetate phthalate), as well as proteins (gelatin, milk proteins) and 
fats are proposed, but the use of gum or biopolymeric matrices is preferred [58-61]. Good reviews about probiotic microencapsulation can be found in the papers of Mitropoulou et al. [62], De Prisco and Mauriello [63], and Terpou et al. [64]. Apart from the kind of material, the performances of probiotic entrapment could be successfully improved through the use of some coadjutants and/or protectants [65-67].

There is literature concerning the use of microencapsulation for the inclusion of probiotics in functional beverages, mainly in functional fruit juices where the low $\mathrm{pH}(2.5-3.7)$ and the presence of phenolic acids (benzoic acid), lactones, and other compounds might affect probiotics' viability. Table 3 shows a brief synopsis of the most recent research on this application, with some details on the technology used, the entrapped probiotics, the juices/beverages where the beads were loaded in, and the most important achievements. Most of these studies focused on the impact of microencapsulation on probiotics' viability and functionality, whereas few have been performed on the evaluation of sensorial properties. Another concern is linked to the experimental temperature, since most of the studies were performed at refrigeration temperature, even if functional beverages are often stored and marketed at room temperature; thus, it might be interesting to evaluate capsules' performances at $20-25^{\circ} \mathrm{C}$.

\section{Engineering}

The performance of probiotic strains can be improved by bioengineering, that is, the manipulation of a gene to improve the tolerance to technological stress, including but not limited to temperature extremes, oxygen and acidification, during food production, and/or survival of the probiotic in the gut, to confer beneficial effects to the host [68].

Bioengineering of probiotics is not an entirely new field, and genetically engineered microorganisms have been shown to efficiently produce and secrete various proteins as well as be capable of treating obesity, diabetes, and colitis in animal models (Table 4). LAB, Saccharomyces spp., Escherichia coli Nissle 1917, and some Bacillus species are the prospective species whose efficiency and utility should be improved for them to be used as probiotics [69]. For example, recent reports support the use of recombinant probiotic yeast Saccharomyces boulardii to synthesize and deliver therapeutic biomolecules during gastro-intestinal tract colonization [70].

One of the main drawbacks of working with bioengineered probiotics is that they are classified as genetically modified organisms (GMOs) [68]. Engineered probiotics contain additional elements for inducing antigenicity and immunomodulation; however, these changes could also affect metabolic pathways and safety [69]. For instance, UV mutagenesis for S. boulardii is not limited to the URA3 gene only, and many other unknown mutations might occur during UV treatment. These unknown mutations may lead to altered phenotypes related to probiotic traits, including undesirable ones [71].

Other than the issue of biocontainment, interactions between synthetic probiotics and the commensal microbes in the human body remain poorly understood. Although significant results are observed in various in vivo models, similar effects may not be observed in humans as the human enteric microbiome is far more complex than that of animal models [72]. Therefore, large, well-designed, randomized controlled clinical trials along with culture-independent metagenomic analyses should be meticulously carried out [69].

Another approach related to bioengineering is the pangenome approach, based on the complete genome sequences of a number of members of the same species [73]. The pangenome is the global gene repertoire of a bacterial species, composed of a core genome (pool of genes shared by all strains of a species) and dispensable genome (the genes of some strains) [74]. Often, the probiotic functions are described and encoded by dispensable genes; therefore, knowledge of the full genome is a prerequisite for a proper selection of functional microorganisms [75], as well as for their improvement through engineering. 


\section{Physical Treatments}

The performances of probiotics in food could be significantly improved and/or modulated using preliminary physical treatments able to exert a stimulus or a metabolic delay. This section addresses the use of two emerging nonthermal technologies (US, ultrasound; $\mathrm{HPH}$, high pressure of homogenization).

\subsection{Ultrasound}

Bevilacqua et al. [76] reported that US can affect microorganisms through a lethal effect or through the stimulation of growth, depending on the intensity and the frequency: High-intensity US impairs the membranes, leading to loss of viability, whereas low-intensity US stimulates bacterial metabolism. Concerning probiotics, the growth and stimulation of metabolism is desirable, and therefore, US is applied by opportunely modulating intensity and frequency.

Several studies have focused on dairy products, but nondairy beverages have also been investigated. In 2011, Yeo and Liong [77] studied the effect of US on the growth of Bifidobacterium FTDC 8943, B. longum FTDC8643, Lactobacillus sp. FTDC2113, and Lb. casei ATCC393 inoculated in soymilk, and they reported that the growth of probiotics was significantly decreased $(p<0.05)$ immediately after the treatment, as a result of membrane permeabilization, cell lysis, and membrane lipid peroxidation. US also caused alteration at the acyl chain, polar head, and interface region of the probiotic membrane phospholipid bilayers. However, the effect was transient, because cells repaired injury and showed a growth kinetic similar to the control. 
Table 3. Synopsis of the most recent research on the use of microencapsulated probiotics into functional beverages. B., Bifidobacterium; Lb., Lactobacillus; S., Saccharomyces.

\begin{tabular}{|c|c|c|c|c|c|c|}
\hline Juice & $\begin{array}{c}\text { Microencapsulated } \\
\text { Probiotic }\end{array}$ & Technique & Protective Matrix & Method & Main Result & Reference \\
\hline Acerola nectar & B. animalis & Spray drying & $\begin{array}{l}\text { Cellulose acetate phthalate } \\
\text { (CAP) }\end{array}$ & $\begin{array}{l}\text { The probiotic was added to a mixture of CAP, } \\
\text { glycerol, maltodextrin, reconstituted milk, } \\
\text { himaize and trehalose and spray-dried at } 110 \\
{ }^{\circ} \mathrm{C} \text {, air flow of } 439 \mathrm{l} / \mathrm{h} \text { and outflow of } 6 \mathrm{~mL} / \mathrm{min} \text {. }\end{array}$ & $\begin{array}{l}\text { The microcapsules stored at } 5^{\circ} \mathrm{C} \text { for } 30 \\
\text { days showed an enhanced viability. }\end{array}$ & [78] \\
\hline Apple juice & Lb. rhamnosus LGG & Spray-drying & $\begin{array}{l}\text { Whey proteins isolate (WP) } \\
\text { and resistant starch (RS) } \\
\text { matrices mixed in different } \\
\text { ratio }\end{array}$ & $\begin{array}{l}\text { The probiotic was added to the encapsulant } \\
\text { formulations and spray-dried at inlet and } \\
\text { outlet temperatures of } 160 \text { and } 65^{\circ} \mathrm{C} \text {. }\end{array}$ & $\begin{array}{l}\text { Microcapsules with higher WP favored a } \\
\text { higher probiotic survival. }\end{array}$ & [79] \\
\hline Berry juice & S. cerevisiae boulardii & Extrusion & $\begin{array}{l}\text { Sodium } \\
\text { alginate-inulin-xanthan gum }\end{array}$ & $\begin{array}{l}\text { The probiotic was added to a mixture } \\
\text { containing sodium alginate, inulin, and } \\
\text { xanthan gum and dropped from a syringe into } \\
\text { a gelling solution containing } \mathrm{CaCl}_{2} \text { at room } \\
\text { temperature. The capsules were shaken for } 30 \\
\text { min and recovered by filtration. }\end{array}$ & Beads improved cell survival. & [80] \\
\hline Carrot juice & Lb. casei-01 & $\begin{array}{l}\text { Spray-drying } \\
\text { and } \\
\text { freeze-drying }\end{array}$ & $\begin{array}{l}\text { Sodium alginate and FOS } \\
\text { (fructooligosaccharides) }\end{array}$ & $\begin{array}{l}\text { An aqueous probiotic solution, alginate and } \\
\text { FOS was infused into a spray-drying with inlet } \\
\text { and outlet temperatures of } 120 \text { and } 60^{\circ} \mathrm{C} \text { (flow } \\
\text { rate } 6 \mathrm{~mL} / \mathrm{min} \text { ). The microparticles were } \\
\text { hardened in a solution containing } \mathrm{CaCl}_{2} \text { and } \\
\text { chitosan and then freeze-dried at } 0.070 \mathrm{mbar} \\
\text { and }-50^{\circ} \mathrm{C} \text { for } 24 \mathrm{~h} \text {. }\end{array}$ & Beads improved cell survival. & [81] \\
\hline Carrot juice & Lb. acidophilus & Extrusion & $\begin{array}{l}\text { Sodium } \\
\text { alginate-inulin-xanthan gum }\end{array}$ & $\begin{array}{l}\text { The solution with the encapsulant matrices } \\
\text { and the microbial culture were dropped from a } \\
10 \mathrm{~mL} \text { syringe into a gelling solution }\left(\mathrm{CaCl}_{2}\right) \text { at } \\
\text { room temperature, shaken for } 30 \mathrm{~min} \text { and } \\
\text { recovered by filtration. }\end{array}$ & $\begin{array}{l}\text { Encapsulation significantly enhanced cell } \\
\text { viability after fermentation and storage. }\end{array}$ & [44] \\
\hline $\begin{array}{l}\text { Cranberry and } \\
\text { pomegranate } \\
\text { juices }\end{array}$ & Lb. rhamnosus LGG & Extrusion & $\begin{array}{l}\text { WP matrices. } \\
\text { Coating with hydrocolloids: } \\
\text { apple pectin, citrus pectin, } \\
\text { sodium alginate, } \\
\text { kappa-carrageenan, } \\
\text { iota-carrageenan, and inulin. }\end{array}$ & $\begin{array}{l}\text { Probiotic cultures were blended with WP and } \\
\text { extruded through a nozzle for collection } \\
\text { within an acetate curing media at } 35^{\circ} \mathrm{C} \text { using } \\
\text { an encapsulator. Then all microbeads were } \\
\text { single and double coated by immersion in } \\
\text { hydrocolloids, at room temperature. }\end{array}$ & $\begin{array}{l}\text { WP protected cells during a } \\
\text { 28-days storage } \\
\text { WP plus apple pectin provided the } \\
\text { higher level of protection under } \\
\text { gastrointestinal conditions. }\end{array}$ & [52] \\
\hline $\begin{array}{l}\text { Cranberry and } \\
\text { pomegranate } \\
\text { juices }\end{array}$ & $\begin{array}{l}\text { Lb. plantarum and } B . \\
\text { longum }\end{array}$ & Extrusion & $\begin{array}{l}\text { Sodium alginate or pectin. } \\
\text { Coating with chitosan, gelatin, } \\
\text { and glucomannan. }\end{array}$ & $\begin{array}{l}\text { The cell suspension was mixed with sodium } \\
\text { alginate or pectin and extruded through a } 0.8 \\
\text { mm diameter needle into a gelling solution } \\
\left(\mathrm{CaCl}_{2}\right) \text { at room temperature, shaken for } 30 \\
\text { min and recovered by filtration. } \\
\text { These beads were single- or double-coated in } \\
\text { chitosan, gelatin, or glucomannan solutions. }\end{array}$ & Beads improved cell survival. & [82] \\
\hline
\end{tabular}


Table 3. Cont.

\begin{tabular}{|c|c|c|c|c|c|c|}
\hline Fermented milk & Lb. casei АТCС 393 & Freeze drying & Chios mastic gum & $\begin{array}{l}\text { Freeze-drying was applied at } 5 \times 10^{-3} \text { bar and } \\
\text { at } 45^{\circ} \mathrm{C} \text { in a freeze-drying system. }\end{array}$ & $\begin{array}{l}\text { Probiotic cell counts retained their high } \\
\text { cell counts }\left(>10^{9} \mathrm{CFU} \mathrm{g}^{-1}\right) \text { during } 8 \\
\text { weeks of storage. }\end{array}$ & [61] \\
\hline Fruit juices & B. longum, B. breve & Freeze drying & Poly- $\gamma$-glutamic acid $(\gamma$-PGA) & $\begin{array}{l}\text { Probiotic cells were suspended in } \gamma \text {-PGA }(10 \% \\
\mathrm{w} / \mathrm{V}) \text {, incubated at room temperature for } 1 \mathrm{~h} \text {, } \\
\text { at }-800^{\circ} \mathrm{C} \text { for } 24 \mathrm{~h} \text { and freeze dried at }-40{ }^{\circ} \mathrm{C} \\
\text { and } 5 \mathrm{mbar} \text { for } 48 \mathrm{~h} \text {. }\end{array}$ & $\begin{array}{l}\text { Bifidobacteria higher viability in orange } \\
\text { and pomegranate juices ( } 39 \text { and } 11 \text { days). }\end{array}$ & [83] \\
\hline $\begin{array}{l}\text { Iranian yogurt } \\
\text { drink (Doogh) }\end{array}$ & $\begin{array}{l}\text { Lb. acidophilus LA-5 } \\
\text { and B. lactis Bb-12 }\end{array}$ & Emulsion & Sodium alginate & $\begin{array}{l}\text { The mixture probiotic/alginate was dispensed } \\
\text { by a pipette into a solution of pure corn oil at } \\
\text { room temperature. The emulsion was broken } \\
\text { through the addition of calcium chloride and } \\
\text { the beads were recovered by centrifugation. }\end{array}$ & $\begin{array}{l}\text { Microencapsulation improves probiotic } \\
\text { viability, during storage at } 4{ }^{\circ} \mathrm{C} \text { for } 42 \\
\text { days. }\end{array}$ & [84] \\
\hline Kefir & B. animalis & Extrusion & Sodium alginate & $\begin{array}{l}\text { The mixture probiotic/alginate was allowed to } \\
\text { drip slowly through a needle into a solution of } \\
\text { calcium chloride at room temperature. }\end{array}$ & $\begin{array}{l}\text { Encapsulation improved significantly the } \\
\text { survival of bifidobacteria during } \\
\text { exposure to nisin, during the storage } \\
\text { period, and in simulated gastric juice. }\end{array}$ & [85] \\
\hline Longan juice & $\begin{array}{l}\text { Lb. acidophilus LA5, } \\
\text { L. casei } 01\end{array}$ & Emulsion & $\begin{array}{c}\text { Alginate. } \\
\text { Coating with sodium alginate. }\end{array}$ & $\begin{array}{l}\text { The mixture probiotic/alginate was dispersed } \\
\text { into a solution of peanut oil at room } \\
\text { temperature. The emulsion was broken } \\
\text { through the addition of calcium chloride, and } \\
\text { the beads were recovered by centrifugation } \\
\text { and coated with sodium alginate. }\end{array}$ & $\begin{array}{l}\text { Encapsulated probiotics could survive in } \\
\text { the acidic environment of the stomach } \\
\text { and small intestine, while the free cells } \\
\text { were completely eliminated. }\end{array}$ & [86] \\
\hline Mango juice & Lb. plantarum & Gelation & $\begin{array}{l}\text { Calcium alginate-soy protein } \\
\text { isolate }\end{array}$ & $\begin{array}{l}\text { Different mixtures with alginate, soy protein } \\
\text { isolates, and probiotic cells were dropped into } \\
\text { a gelation bath containing calcium chloride } \\
\text { using a needle at a constant flow rate of } 3.6 \\
\mathrm{~mL} / \text { min through a peristaltic pump, at room } \\
\text { temperature. }\end{array}$ & $\begin{array}{l}\text { The application of encapsulated beads in } \\
\text { mango juice showed successful resistance } \\
\text { to thermal conditions. }\end{array}$ & [87] \\
\hline $\begin{array}{l}\text { Orange and } \\
\text { peach juices }\end{array}$ & Lb. paracasei L26 & Extrusion & $\begin{array}{l}\text { Sodium alginate. } \\
\text { Coating with chitosan or } \\
\text { dextran }\end{array}$ & $\begin{array}{l}\text { The alginate/culture mixture was extruded } \\
\text { using a microincapsulator with a } 0.5 \mathrm{~mm} \\
\text { orifice, a nitrogen pressure of } 0.4 \text { bar, and an } \\
\text { extrusion rate of } 4 \mathrm{~mL} / \mathrm{min} \text {. The microcapsules } \\
\text { were left in a solution containing calcium } \\
\text { chloride for } 30 \text { min at room temperature. Once } \\
\text { recovered by gravity filtration, the beads were } \\
\text { single- or double-coated with chitosan } \\
\text { or dextran. }\end{array}$ & $\begin{array}{l}\text { Free cells have a greater metabolic activity } \\
\text { than microencapsulated ones. }\end{array}$ & [88] \\
\hline Orange juice & $\begin{array}{l}\text { Lb. acidophilus LA5 } \\
\text { and Lb. casei } 01\end{array}$ & Extrusion & $\begin{array}{c}\text { Sodium alginate and } \\
\text { galactooligosaccharides (GOS) } \\
\text { or inulin. } \\
\text { Coating with chitosan. }\end{array}$ & $\begin{array}{l}\text { The solution containing alginate and GOS or } \\
\text { inulin was mixed with probiotic suspension } \\
\text { and injected through a needle into a gelation } \\
\text { solution containing calcium chloride for } 30 \\
\text { min at room temperature. } \\
\text { Then, the beads were coated with chitosan. }\end{array}$ & Beads improved cell survival. & [89] \\
\hline
\end{tabular}




\begin{tabular}{|c|c|c|c|c|c|c|}
\hline $\begin{array}{l}\text { Pomegranate } \\
\text { juice }\end{array}$ & Lb. plantarum & Extrusion & $\begin{array}{l}\text { Sodium alginate. } \\
\text { Single or double coating with } \\
\text { chitosan. }\end{array}$ & $\begin{array}{l}\text { The cell suspension/alginate mixture was } \\
\text { extruded through a needle into a solution } \\
\text { containing calcium chloride at room } \\
\text { temperature. Then, the beads were single- or } \\
\text { double-coated in chitosan. }\end{array}$ & $\begin{array}{l}\text { Chitosan coating increased the protection } \\
\text { provided by alginate beads. }\end{array}$ & {$[90]$} \\
\hline $\begin{array}{c}\text { Soured } \\
\text { fermented milk }\end{array}$ & B. lactis DSM 10140 & Extrusion & Gellan and xanthan gums & $\begin{array}{l}\text { The probiotic was added to gellan and } \\
\text { xanthan gum at } 55^{\circ} \mathrm{C} \text {, and the solution was } \\
\text { extruded through a needle into a solution } \\
\text { containing calcium chloride. Microcapsules } \\
\text { were recovered by filtration. }\end{array}$ & $\begin{array}{l}\text { Microencapsulation of } B \text {. lactis enhanced } \\
\text { survival over a } 21 \text {-day period as } \\
\text { compared to free cells. }\end{array}$ & [91] \\
\hline Tomato juice & Lb. acidophilus & Extrusion & Sodium alginate & $\begin{array}{l}\text { The probiotic/alginate solution was extruded } \\
\text { as droplets through a needle using a peristaltic } \\
\text { pump into a solution containing calcium } \\
\text { chloride, at room temperature. }\end{array}$ & $\begin{array}{l}\text { The immobilized cells endured the } \\
\text { adverse effects of tomato juice, } \\
\text { maintaining high viable counts. }\end{array}$ & [92] \\
\hline
\end{tabular}


Table 4. Bioengineered microorganisms intended as probiotics in humans. Lb., Lactobacillus; S., Saccharomyces; Lc., Lactococcus; E., Escherichia.

\begin{tabular}{|c|c|c|}
\hline Probiotics & Modified Properties & References \\
\hline \multicolumn{3}{|c|}{ Lactobacillus } \\
\hline Lb. paracasei & $\begin{array}{l}\text { Improved thermotolerance } \\
\text { Increased resistance to some solvents } \\
\text { Inhibition of adhesion of Listeria to host cells }\end{array}$ & [68] \\
\hline Lb. salivarius & Increased resistance to several stresses & [68] \\
\hline Lb. jensenii & Inhibition of $\mathrm{HIV}$ in $\mathrm{CD}^{+}$cells and macrophages & [69] \\
\hline Lb. reuteri & $\begin{array}{l}\text { Binding of some enterotoxins and prevention of their } \\
\text { toxicity in a mouse model }\end{array}$ & [68] \\
\hline Lb. acidophilus & $\begin{array}{l}\text { Reduction of attachment of Escherichia coli ETEC to porcine } \\
\text { intestinal brush border }\end{array}$ & [68] \\
\hline Lb. gasseri & Alleviation of diabetes Mellitus in rat model & [93] \\
\hline Lb. plantarum & Decreased systolic blood pressure in rats & [72] \\
\hline \multicolumn{3}{|c|}{ Lactococcus } \\
\hline Lc. lactis & $\begin{array}{l}\text { Enhanced resistance to gastric acid damage } \\
\text { Enhanced efficient internalization in human intestinal cell } \\
\text { line Caco-2 } \\
\text { Inhibition of E. coli and Salmonella } \\
\text { Overall reduction of inflammation and colitis } \\
\text { Prevention of colitis in murine models } \\
\text { Protection against rotavirus infection }\end{array}$ & [68] \\
\hline Lc. lactis & $\begin{array}{l}\text { Prevention of allergen-induced airway inflammation by } \\
\text { induction of specific mucosal immune tolerance }\end{array}$ & [69] \\
\hline Lc. lactis & Improved repair of gut epithelial damage in Hamster model & [69] \\
\hline \multicolumn{3}{|c|}{ Other Microorganisms } \\
\hline Probiotic E. coli & Binding of enterotoxins & {$[68]$} \\
\hline E. coli Nissle 1917 & Protection against Vibrio cholerae & [68] \\
\hline E. coli Nissle 1917 & Elimination/inactivation pf Pseudomonas mice model & [93] \\
\hline B. longum & Reduction of colitis inflammation & [94] \\
\hline Bacillus subtilis & $\begin{array}{l}\text { Prolonged colonization of recombinant B. subtilis in GI tract } \\
\text { of mice, significant reduction in H. pylori }(84 \%)\end{array}$ & [69] \\
\hline S. boulardii & Secretory expression of biologically active IL-10 & [69] \\
\hline
\end{tabular}

A treatment at $100 \mathrm{~W}$ for 2 and 3 min also enhanced $(p<0.05)$ intracellular and extracellular $\beta$-glucosidase activity of probiotics, leading to increased $(p<0.05)$ bioconversion of glucosides to aglycones in the prebiotic-soymilk.

Recently, Gholamhosseinpour and Hashemi [95] used US (100 W, $30 \mathrm{kHz}, 25 \%$ amplitude for 5, 10, and $15 \mathrm{~min}$ ) to improve the metabolism and growth of $\mathrm{Lb}$. plantarum AF1 during milk fermentation at $37{ }^{\circ} \mathrm{C}$. The results showed an increase on the quality and antioxidant activity of milk, probably related to an increased cell concentration $(8.7 \log \mathrm{CFU} / \mathrm{mL}$ in the control; $>9 \log \mathrm{CFU} / \mathrm{mL}$ in US-treated samples) and a reduced lag phase.

Niamah [96] studied the effect of US at $40 \mathrm{kHz}$ for $0,5,10,15$, and $20 \mathrm{~min}$ on the growth of $L b$. acidophilus LA-5, Lb. casei LC, Lb. reuteri LR-MM53, B. bifidum Bb-12 and B. longum BB-536 in fermented milk. A US-treatment for $10 \mathrm{~min}$ improved chemical properties of fermented milk by probiotics. A further increase of exposure time caused a reduction of viability of probiotic bacteria strains and increased $\beta$-galactosidase activity.

Costa et al. [97] inoculated Lb. casei NRRL B442 in a sonicated pineapple juice (sonication at $376 \mathrm{~W}$ $\mathrm{cm}^{-2}$ for $10 \mathrm{~min}$ with a $1.3 \mathrm{~cm}$ probe tip and at a constant ultrasonic frequency of $19 \mathrm{kHz}$ ); the treatment enhanced the performance of the probiotic, which then was able to survive for at least 21 days at $4{ }^{\circ} \mathrm{C}$. In addition, sonication reduced the impact of browning throughout storage.

Bevilacqua et al. [7,76] and Racioppo et al. [98] studied a different use of US, the possibility of a modulation or an attenuation of the metabolism of probiotics with a strong reduction of the post-acidification occurring during storage. This treatment $(50-80 \mathrm{~W})$ was applied on the probiotic 
( $L b$. reuteri, $L b$. plantarum, $L b$. casei, bifidobacteria, and propionibacteria) before the inoculation in an organic rice beverage or in model systems and assured the maintenance of $\mathrm{pH}$ and sensory scores for at least 7 days.

\subsection{High-Pressure Homogenization}

$\mathrm{HPH}$ action depends mainly on microbial and physiological parameters, process parameters, and characteristics of fluids [76]. On the other hand, HPH can also exert a positive effect by modulating the metabolism of microorganisms: in fact, $\mathrm{HPH}$ can control the fermentation kinetics of starters and modify their metabolic activity with an enhancement of sensorial properties [76].

Patrignani et al. [99] reported that HPH could be used in fermented milk for several reasons: (1) to modulate the sensorial characteristics without harmful effects on shelf life and safety; (2) to improve the technological performances of probiotics; and (3) to change the functional features of lactic acid bacteria.

An exhaustive discussion on the actual scenario concerning HPH treatment of functional dairy beverages was reported by Patrignani et al. [99]. In particular, the authors mentioned a previous study on the effect of HPH on nonfat milk solids and milk fat on the technological performances of $L b$. paracasei BFE 5264 for the production of probiotic fermented milks [100] and reported that the use of treatments at 20-100 MPa could improve the sensorial properties of fermented milk. With nonfat milk solid $<3 \%$, firmness, viscosity index, and consistency of probiotic fermented milk increased with the increase in pressure level; the content of diacetyl and acetaldehyde increased, too. Moreover, $L b$. paracasei BFE 5264 coagulation time was significantly affected by the increase of pressure depending on the addition phase of milk fat (before or after the pressure treatment): When the addition of milk fat was performed before HPH treatment, the strain fermentation rate decreased, and its viability during the refrigerated storage was reduced.

Optimal results were also obtained when the authors studied the effect of HPH for the production of probiotic fermented milk containing $L b$. paracase $i$ and $L b$. acidophilus. In fact, compared to heat-treated milk, HPH-milk favored the viability of starter cultures (Streptococcus thermophilus and Lb. delbrueckii subsp. bulgaricus) and the probiotic strains ( $L b$. acidophilus and $L b$. paracasei). In addition, higher values of firmness, consistency, cohesiveness, and viscosity indices were also observed.

Finally, Bevilacqua et al. [7] used HPH for the attenuation of lactic acid bacteria in an organic rice beverage and found that the effect of multiple passes at 100 MPa delayed acidification by 4 days and reduced the maximum extent of the acidification; thus, the authors proposed this approach as a tool for attenuation to counteract the acidification of promising probiotics and to avoid the post-acidification of the rice beverage throughout storage.

Apart from $\mathrm{HPH}$, other possible approaches to achieve attenuation are mild heat treatment (for example, $46{ }^{\circ} \mathrm{C}$ for $1 \mathrm{~h}$ for Lb. rhamnosus) [101], or random mutagenesis [102].

\section{Conclusions}

Probiotication of beverages is one of the increasing trends for research and industry; however, the inoculation of probiotics in some beverages is a challenge, as some issues should be addressed. First, probiotics have to resist certain technological stresses, such as low $\mathrm{pH}$, presence of antimicrobial compounds, high osmotic pressure, and oxygen, and researchers have to face the threat of the effect of probiotics on some sensory attributes.

This review discussed several approaches to counteract these phenomena. The resistance of probiotics could be increased by either cross-adaptation/adaptive evolution or by bioengineering, while a solution for sensory traits is attenuation (physical treatments). Each protocol has benefits and limits, but some issues must be clarified and the lack of data on them is a challenge, that is:

(a) The effect of each treatment on consumer perception;

(b) Safety and metabolic profiles of treated microorganisms, in order to assess that these approaches do not promote risk profile and do not modify desired metabolic pathways; 
(c) The effect of each treatment on the functional and probiotic patterns of probiotic microorganisms;

(d) The effect of each treatment on the costs.

A final and important point relates to strain specificity of the treatments, as each approach is strongly affected by the strain, while for an industrial application, it is important to design general processes that might be applied to a large number of microorganisms.

Author Contributions: Conceptualization, M.S., A.B., and M.R.C.; writing-original draft preparation, B.S., D.C., and L.P.; writing-review and editing, A.B. and C.A.; supervision, M.S. and M.R.C. All authors have read and agreed to the published version of the manuscript.

Funding: This research received no external funding.

Conflicts of Interest: The authors declare no conflict of interest.

\section{References}

1. Mustafa, S.M.; Chua, L.S.; El Enshasy, H.A.; Majid, F.A.A.; Malek, R.A. A Review on fruit juice probiotication: Pomegranate. Curr. Nutr. Food Sci. 2016, 12, 4-11. [CrossRef]

2. Mustafa, S.M.; Chua, L.S.; El-Enshasy, H.A.; Majid, F.A.A.; Hanapi, S.Z.; Abdul Malik, R. Effect of temperature and $\mathrm{pH}$ on the probiotication of Punica granatum juice using Lactobacillus species. J. Food Biochem. 2019, 43, e12805. [CrossRef] [PubMed]

3. Tayo, B.A.; Akpeji, S. Probiotic viability, physicochemical and sensory properties of probiotic pineapple juice. Fermentation 2016, 2, 2040020.

4. Thakkar, P.; Vaghela, B.; Patel, A.; Modi, H.A.; Prajapati, J.B. Formulation and shelf life study of a whey-based functional beverage containing orange juice and probiotic organisms. Int. J. Food Res. 2018, 25, 1675-1681.

5. Malik, M.; Bora, J.; Sharma, V. Growth studies of potentially probiotic lactic acid bacteria (Lactobacillus plantarum, Lactobacillus acidophilus, and Lactobacillus casei) in carrot and beetroot juice substrates. J. Food Process. Pres. 2019, 43, e14214. [CrossRef]

6. Huang, M.L.; Huang, J.Y.; Kao, C.Y.; Fang, T.J. Fermented soymilk and soy and cow milk mixture, supplemented with orange peel fiber or Tremella flava fermented powder as prebiotics for high exopolysaccharide-producing Lactobacillus pentosus SLC 13. J. Sci. Food Agric. 2019, 99, 4373-4382. [CrossRef]

7. Bevilacqua, A.; Casanova, F.P.; Petruzzi, L.; Sinigaglia, M.; Corbo, M.R. Using physical approaches for the attenuation of lactic acid bacteria in an organic rice beverage. Food Microbiol. 2016, 53, 1-8. [CrossRef]

8. Balthazar, C.F.; Santillo, A.; Guimarães, J.T.; Capozzi, V.; Russo, P.; Caroprese, M.; Marino, R.; Esmerino, E.A.; Renata Raices, S.L.; Silva, M.C.; et al. Novel milk-juice beverage with fermented sheep milk and strawberry (Fragaria $\times$ ananassa): Nutritional and functional characterization. J. Dairy Sci. 2019, 102, 10724-10736. [CrossRef]

9. Guerra, A.F.; Junior, L.; Fernandes, W.L.; Santos, G.O.D.; Andrighetto, C.; Gianomini, A.; Corich, V.; Luchese, R.H. Lactobacillus paracasei probiotic properties and survivability under stress-induced by processing and storage of ice cream bar or ice-lolly. Ciência Rural 2018, 48, 09-e20170601. [CrossRef]

10. Pasqualone, A.; Summo, C.; Laddomada, B.; Mudura, E.; Coldea, T.E. Effect of processing variables on the physico-chemical characteristics and aroma of borş, a traditional beverage derived from wheat bran. Food Chem. 2018, 265, 242-252. [CrossRef]

11. Enujiugha, V.N.; Badejo, A.A. Probiotic potentials of cereal-based beverages. Crit. Rev. Food Sci. Nutr. 2017, 57, 790-804. [CrossRef] [PubMed]

12. Chaudary, A. Probiotic Fruit and Vegetable Juices: Approach Towards a Healthy Gut. Int. J. Curr. Microbiol. App. Sci. 2019, 8, 1265-1279. [CrossRef]

13. Markowiak, P.; Slizewska, K. Effects of probiotics, prebiotics and synbiotics on human health. Nutrients 2017, 9, 1021. [CrossRef] [PubMed]

14. Hamasalim, H.J. Synbiotic as feed additives relating to animal health and performance. Adv. Microbiol. 2016, 6, 288-302. [CrossRef]

15. Manigandan, T.; Mangaiyarkarasi, S.P.; Hemaltha, R.; Hemaltha, V.T.; Murali, N.P. Probiotics, prebiotics and synbiotics-A review. BioMed. Pharmacol. J. 2012, 5, 295-304. [CrossRef]

16. Zhang, M.M.; Cheng, J.Q.; Lu, Y.R.; Yi, Z.H.; Yang, P.; Wu, X.T. Use of pre-, pro-and synbiotics in patients with acute pancreatitis: A meta-analysis. World J. Gastroenterol. 2010, 16, 3970. [CrossRef] [PubMed] 
17. Lemos, J.W.; Guerra, A.F.; Tarrah, A.; da Silva, D.V.; Giacomini, A.; Luchese, R.H.; Corich, V. Safety and stability of two potentially probiotic Lactobacillus strains after in vitro gastrointestinal transit. Probiotics Antimicrob. Proteins 2019. [CrossRef]

18. Zhang, Y.; Li, Y. Engineering the antioxidative properties of lactic acid bacteria for improving its robustness. Curr. Opin. Biotechnol. 2013, 24, 142-147. [CrossRef]

19. Papadimitriou, K.; Alegrìa, A.; Bron, P.A.; de Angelis, M.; Gobbetti, M.; Kleerebezem, M.; Lemos, J.A.; Linares, D.M.; Ross, P.; Stanton, C.; et al. Stress physiology of lactic acid bacteria. Appl. Environ. Microbiol. 2016, 80, 837-890. [CrossRef]

20. Bucka-Kolendo, J.; Sokolowska, B. Lactic acid bacteria stress response to preservation processes in the beverage and juice industry. Acta Biochim. Pol. 2017, 64, 459-464. [CrossRef]

21. Gaucher, F.; Bonnassie, S.; Rabah, H.; Marchand, P.; Blanc, P.; Jeantet, R.; Jan, G. Review: Adaptation of beneficial propionibacteria, lactobacilli, and bifidobacteria improves tolerance toward technological and digestive stresses. Front. Microbiol. 2019, 10, 841. [CrossRef] [PubMed]

22. Hill, C.; Guarner, F.; Reid, G.; Gibson, G.R.; Merenstein, D.J.; Pot, B.; Morelli, L.; Canani, R.B.; Flint, H.J.; Salminen, S.; et al. The International Scientific Association for Probiotics and Prebiotics consensus statement on the scope and appropriate use of the term probiotic. Nat. Rev. Gastro. Hepat. 2014, 11, 506-514. [CrossRef] [PubMed]

23. Van de Guchte, M.; Serror, P.; Chervaux, C.; Smokvina, T.; Ehrlich, S.D.; Maguin, E. Stress response in lactic acid bacteria. Antonie Van Leeuwenhoek 2002, 82, 187-216. [CrossRef] [PubMed]

24. Varhimo, E.; Savijoki, K.; Jalava, J.; Kuipers, O.P.; Varmanen, P. Identification of a novel streptococcal gene cassette mediating SOS mutagenesis in Streptococcus uberis. J. Bacteriol 2007, 189, 5210-5222. [CrossRef] [PubMed]

25. Machielsen, R.; van Alen-Boerrigter, I.J.; Koole, L.A.; Bongers, R.S.; Kleerebezem, M.; Van Hylckama Vlieg, J.E.T. Indigenous and environmental modulation of frequencies of mutation in Lactobacillus plantarum. Appl. Environ. Microbiol. 2010, 76, 1587-1595. [CrossRef] [PubMed]

26. Perricone, M.; Corbo, M.R.; Sinigaglia, M.; Speranza, B.; Bevilacqua, A. Viability of Lactobacillus reuteri in fruit juices. J. Funct. Food 2014, 10, 421-426. [CrossRef]

27. Broadbent, J.R.; Larsen, R.L.; Deibel, V.; Steele, J.L. Physiological and transcriptional response of Lactobacillus casei ATCC 334 to acid stress. J. Bacteriol. 2010, 192, 2445-2458. [CrossRef]

28. Bevilacqua, A.; Sinigaglia, M.; Corbo, M.R. An acid/alkaline stress and the addition of amino acids induce a prolonged viability of Lactobacillus plantarum loaded into alginate gels. Int. J. Food Microbiol. 2010, 142, 242-246. [CrossRef]

29. Huang, S.; Rabah, H.; Jardin, J.; Briard-Bion, V.; Parayre, S.; Maillard, M.B.; Le Loir, Y.; Chen, X.D.; Pierre Schuck, P.; Romain Jeantet, R.; et al. Hyperconcentrated sweet whey, a new culture medium that enhances Propionibacterium freudenreichii stress tolerance. Appl. Environ. Microbiol. 2016, 82, 4641-4651. [CrossRef]

30. Huang, S.; Gaucher, F.; Cauty, C.; Jardin, J.; Le Loir, Y.; Jeantet, R.; Chen, X.D.; Jan, G. Growth in hyper-concentrated sweet whey triggers multi stress tolerance and spray drying survival in Lactobacillus casei BL23: From the molecular basis to new perspectives for sustainable probiotic production. Front. Microbiol. 2018, 9, 2548. [CrossRef]

31. Ferreira, V.; Soares, V.; Santos, C.; Silva, J.; Gibbs, P.A.; Teixeira, P. Survival of Lactobacillus sakei during heating, drying and storage in the dried state when growth has occurred in the presence of sucrose or monosodium glutamate. Biotechnol. Lett. 2005, 27, 249-252. [CrossRef] [PubMed]

32. Carvalho, A.S.; Silva, J.; Ho, P.; Teixeira, P.; Malcata, F.X.; Gibbs, P. Effects of various sugars added to growth and drying media upon thermotolerance and survival throughout storage of freeze-dried Lactobacillus delbrueckii ssp. bulgaricus. Biotechnol. Prog. 2008, 20, 248-254. [CrossRef] [PubMed]

33. Altieri, C.; Bevilacqua, A.; Sinigaglia, M. Prolonging the viability of Lactobacillus plantarum thorugh the addition of prebiotics into the medium. J. Food Sci. 2011, 76, M336-M345. [CrossRef] [PubMed]

34. Altieri, C.; Iorio, M.C.; Bevilacqua, A.; Sinigaglia, M. Influence of prebiotics on Lactobacillus reuteri death kinetics under sub-optimal temperatures and pH. Int. J. Food Nutr. Sci. 2016, 67, 92-98. [CrossRef]

35. Speranza, B.; Bevilacqua, A.; Corbo, M.R.; Sinigaglia, M. A possible approach to assess acidification of meat starter cultures: A case study for some wild strains of Lactobacillus plantarum. J. Sci. Food Agric. 2017, 97, 2691-2698. [CrossRef] 
36. Shin, Y.; Kang, C.H.; Kim, W.; So, J.S. Heat adaptation improved cell viability of probiotic Enterococcus faecium HL7 upon various environmental stresses. Probiotics Antimicrob. Proteins 2019, 11, 618-626. [CrossRef]

37. Shah, N.P.; Ding, W.K.; Fallourd, M.J.; Leyer, G. Improving the stability of probiotic bacteria in model fruit juices using vitamins and antioxidants. J. Food Sci. 2010, 75, M278-M282. [CrossRef]

38. Barrera, C.; Burca, C.; Betoret, E.; García-Hernández, J.; Hernández, M.; Betoret, N. Improving antioxidant properties and probiotic effect of clementine juice inoculated with Lactobacillus salivarius spp. salivarius (CECT 4063) by trehalose addition and/or sublethal homogenisation. Int. J. Food Sci. Technol. 2019, 54, 2109-2122.

39. Da Costa, G.M.; de Carvalho Silva, J.V.; Mingotti, J.D.; Barão, C.E.; Jensen Klososki, S.; Colombo Pimentel, T. Effect of ascorbic acid or oligofructose supplementation on L. paracasei viability, physicochemical characteristics and acceptance of probiotic orange juice. LWT Food Sci. Technol. 2017, 75, 195-201. [CrossRef]

40. Anal, A.K.; Singh, H. Recent advances in microencapsulation of probiotics for industrial applications and targeted delivery. Trends Food Sci. Technol. 2007, 18, 240-251. [CrossRef]

41. Avila-Reyes, S.V.; Garcia-Suarez, F.J.; Jimenez, M.T.; San Martín-Gonzalez, M.F.; Bello-Perez, L.A. Protection of L. rhamnosus by spray-drying using two prebiotics colloids to enhance the viability. Carbohyd. Polym. 2014, 102, 423-430. [CrossRef] [PubMed]

42. Burgain, J.; Gaiani, C.; Linder, M.; Scher, J. Encapsulation of probiotic living cells: From laboratory scale to industrial applications. J. Food Eng. 2011, 104, 467-483. [CrossRef]

43. Fritzen-Freire, C.B.; Prudencio, E.S.; Amboni, R.D.M.C.; Pinto, S.S.; Negrao-Murakami, A.N.; Murakami, F.S. Microencapsulation of bifidobacteria by spray drying in the presence of prebiotics. Food Res. Int. 2012, 45, 306-312. [CrossRef]

44. Nazzaro, F.; Fratianni, F.; Coppola, R.; Sada, A.; Orlando, P. Fermentative ability of alginate-prebiotic encapsulated Lactobacillus acidophilus and survival under simulated gastrointestinal conditions. J. Funct. Food 2009, 1, 319-323. [CrossRef]

45. Yonekura, L.; Sun, H.; Soukoulis, C.; Fisk, I. Microencapsulation of Lactobacillus acidophilus NCIMB 701748 in matrices containing soluble fibre by spray drying: Technological characterization, storage stability and survival after in vitro digestion. J. Funct. Food 2014, 6, 205-214. [CrossRef]

46. Sohail, A.; Turner, M.S.; Coombes, A.; Bostom, T.; Bhandari, B. Survivability of probiotics encapsulated in alginate gel microbeads using a novel impinging aerosols method. Int. J. Food Microbiol. 2011, 145, 162-168. [CrossRef]

47. Nedovic, V.; Kalusevic, A.; Manojlovic, V.; Levic, S.; Bugarski, B. An overview of encapsulation technologies for food applications. Procedia Food Sci. 2011, 1806-1815. [CrossRef]

48. Sidira, M.; Galanis, A.; Ypsilantis, P.; Karapetsas, A.; Progaki, Z.; Simopoulos, C.; Kourkoutas, Y. Effect of probiotic fermented milk administration on gastrointestinal survival of Lactobacillus casei ATCC 393 and modulation of intestinal microbial flora. J. Mol. Microbiol. Biotechnol. 2011, 19, 224-230. [CrossRef]

49. Saucier, L.; Champagne, C. Immobilised-cell technology and meat processing. In Application of Cells Immobilisation Biotechnology; Nedovic, V., Willaert, R., Eds.; Springer: Amsterdam, The Netherland, 2005; Volume 20, pp. 337-353.

50. Heidebach, T.; Forst, P.; Kulozik, U. Microencapsulation of probiotic cells by means of rennet-gelation of milk proteins. Food Hydrocolloid 2009, 23, 1670-1677. [CrossRef]

51. Heidebach, T.; Forst, P.; Kulozik, U. Transglutaminase induced caseinate gelation for the microencapsulation of probiotic cells. Int. Dairy J. 2009, 19, 77-84. [CrossRef]

52. Doherty, S.B.; Auty, M.A.; Stanton, C.; Ross, R.P.; Fitzgerald, G.F.; Brodkorb, A. Application of whey protein micro-bead coatings for enhanced strength and probiotic protection during fruit juice storage and gastric incubation. J. Microencapsul. 2012, 29, 713-728. [CrossRef] [PubMed]

53. Kourkoutas, Y.; Xolias, V.; Kallis, M.; Bezirtzoglou, E.; Kanellaki, M. Lactobacillus casei cell immobilization on fruit pieces for probiotic additive, fermented milk and lactic acid production. Process. Biochem. 2005, 40, 411-416. [CrossRef]

54. Champagne, C.; Lee, B.; Saucier, L. Immobilization of cells and enzymes for fermented dairy or meat products. In Encapsulation Technologies for Active Food Ingredients and Food Processing; Zuidamand, N.J., Nedovic, V.A., Eds.; Springer: New York, NY, USA, 2010; Volume 13, pp. 345-365.

55. Champagne, C.P.; Fustier, P. Microencapsulation for the improved delivery of bioactive compounds into foods. Curr. Opin. Biotechnol. 2007, 18, 184-190. [CrossRef] [PubMed] 
56. Chavarri, M.; Maranon, I.; Villaran, M.C. Encapsulation technology to protect probiotic bacteria. In Probiotics; Everlon, C.R., Ed.; INTECH Publisher: Rijeka, Croatia, 2012; pp. 501-540.

57. Krasaekoopt, W.; Bhandari, B.; Deeth, H. Evaluation of encapsulation techniques of probiotics for yoghurt. Int. Dairy J. 2003, 13, 3-13. [CrossRef]

58. Colín-Cruz, M.A.; Pimentel-González, D.J.; Carrillo-Navas,H.; Alvarez-Ramírez,J.; Guadarrama-Lezama, A.Y. Co-encapsulation of bioactive compounds from blackberry juice and probiotic bacteria in biopolymeric matrices. LWT Food Sci. Technol. 2019, 110, 94-101. [CrossRef]

59. Vega-Sagardía, M.; Rocha, J.; Sáez, K.; Smith, C.T.; Gutierrez-Zamorano, C.; García-Cancino, A. Encapsulation, with and without oil, of biofilm forming Lactobacillus fermentum UCO-979C strain in alginate-xanthan gum and its anti-Helicobacter pylori. J. Funct. Food 2018, 46, 504-513. [CrossRef]

60. Schoina, V.; Terpou, A.; Bosnea, L.; Kanellaki, M.; Nigam, P.S. Entrapment of Lactobacillus casei ATCC393 in the viscus matrix of Pistacia terebinthus resin for functional myzithra cheese manufacture. LWT Food Sci. Technol. 2018, 89, 441-448. [CrossRef]

61. Terpou, A.; Nigam, P.S.; Bosnea, L.; Kanellaki, M. Evaluation of Chios mastic gum as antimicrobial agent and matrix forming material targeting probiotic cell encapsulation for functional fermented milk production. LWT Food Sci. Technol. 2018, 97, 109-116. [CrossRef]

62. Mitropoulou, G.; Nedovic, V.; Goyal, A.; Kourkoutas, Y. Immobilization Technologies in Probiotic Food Production. J. Nutr. Metab. 2013, 2013, e716861. [CrossRef]

63. De Prisco, A.; Mauriello, G. Probiotication of foods: A focus on microencapsulation tool. Trends Food Sci. Technol. 2016, 48, 27-39. [CrossRef]

64. Terpou, A.; Papadaki, A.; Lappa, I.K.; Kachrimanidou, V.; Bosnea, L.A.; Kopsahelis, N. Probiotics in Food Systems: Significance and Emerging Strategies Towards Improved Viability and Delivery of Enhanced Beneficial Value. Nutrients 2019, 11, e1591. [CrossRef] [PubMed]

65. Pop, O.L.; Diaconeasa, Z.; Brandau, T.; Ciuzan, O.; Pamfil, D.; Vodnar, D.C.; Socaciu, C. Effect of glycerol, as cryoprotectant in the encapsulation and freeze drying of microspheres containing probiotic cells. Bull. UASVM Food Sci. Technol. 2015, 72, 27-32. [CrossRef]

66. Pop, O.L.; Brandau, T.; Schwinn, J.; Vodnar, D.C.; Socaciu, C. The influence of different polymers on viability of Bifidobacterium lactis 300b during encapsulation, freeze-drying and storage. J. Food Sci. Technol. 2015, 52, 4146-4155. [CrossRef] [PubMed]

67. Pop, O.L.; Dulf, F.V.; Cuibus, L.; Castro-Giráldez, M.; Fito, P.J.; Vodnar, D.C.; Coman, C.; Socaciu, C.; Suharoschi, S. Characterization of a sea buckthorn extract and its effect on free and encapsulated Lactobacillus casei. Int. J. Mol. Sci. 2017, 18, 2513. [CrossRef] [PubMed]

68. Mathipa, M.G.; Thantsha, M.S. Probiotic engineering: Towards development of robust probiotic strains with enhanced functional properties and for targeted control of enteric pathogens. Gut Pathog. 2017, 9, 28. [CrossRef]

69. Kumar, M.; Yadav, A.K.; Verma, V.; Singh, B.; Mal, G.; Nagpal, R.; Hemalatha, R. Bioengineered probiotics as a new hope for health and diseases: An overview of potential and prospects. Future Microbiol. 2016, 11, 585-600. [CrossRef]

70. Bagherpour, G.; Ghasemi, H.; Zand, B.; Zarei, N.; Roohvand, F.; Ardakani, E.M.; Azizi, M.; Khalaj, V. Oral administration of recombinant Saccharomyces boulardii expressing ovalbumin-CPE fusion protein induces antibody response in mice. Front. Microbiol. 2018, 9, e723. [CrossRef]

71. Liu, J.J.; Kong, I.I.; Zhang, G.C.; Jayakody, L.N.; Kim, H.; Xia, P.F.; Kwak, S.; Sung, B.H.; Sohn, J.H.; Walukiewicz, H.E.; et al. Metabolic engineering of probiotic Saccharomyces boulardii. Appl. Environ. Microbiol. 2016, 82, 2280-2287. [CrossRef]

72. Chua, K.J.; Kwok, W.C.; Aggarwal, N.; Sun, T.; Chang, M.W. Designer probiotics for the prevention and treatment of human diseases. Curr. Opin. Chem. Biol. 2017, 40, 8-16. [CrossRef]

73. Bevilacqua, A.; Fuccio, F.; Iorio, M.C.; Loi, M.; Sinigaglia, M. The role of pangenome concept in selecting starter cultures. In Starter Cultures in Food Production; Speranza, B., Bevilacqua, A., Corbo, M.R., Sinigaglia, M., Eds.; Wiley Blackwell: Oxford, UK, 2017; pp. 162-173.

74. Medini, D.; Donati, C.; Tettelin, H.; Masignani, V.; Rappuoli, R. The microbial pangenome. Curr. Opin. Gen. Dev. 2005, 15, 589-594. [CrossRef] 
75. Junior, W.J.F.L.; Guerra, A.F.; da Silva Duarte, V.; Treu, L.; Tarrah, A.; Campanaro, S.; Luchese, R.H.; Giacomini, A.; Corich, V. Draft genome sequence data of Lactobacillus paracasei strain DTA83 isolated from infant stools. Data Brief 2019, 22, 1064-1067. [CrossRef]

76. Bevilacqua, A.; Campaniello, D.; Speranza, B.; Altieri, C.; Sinigaglia, M.; Corbo, M.R. Two Nonthermal Technologies for Food Safety and Quality-Ultrasound and High Pressure Homogenization: Effects on Microorganisms, Advances, and Possibilities: A Review. J. Food Protect. 2019, 82, 2049-2064. [CrossRef] [PubMed]

77. Yeo, S.K.; Liong, M.T. Effect of Ultrasound on the Growth of Probiotics and Bioconversion of Isoflavones in Prebiotic-Supplemented Soymilk. J. Agric. Food Chem. 2011, 59, 885-897. [CrossRef] [PubMed]

78. Antunes, A.E.C.; Liserre, A.M.; Coelho, A.L.A.; Menezes, C.R.; Moreno, I.; Yotsuyanagi, K.; Azambuja, N.C. Acerola nectar with added microencapsulated probiotic. LWT Food Sci. Technol. 2013, 54, 125-131. [CrossRef]

79. Ying, D.; Schwander, S.; Weerakkody, R.; Sanguansri, L.; Gantenbein-Demarchi, C.; Augustin, M.A. Microencapsulated Lactobacillus rhamnosus GG in whey protein and resistant starch matrices: Probiotic survival in fruit juice. J. Funct. Food 2013, 5, 98-105. [CrossRef]

80. Fratianni, F.; Cardinale, F.; Russo, I.; Tremonte, P.; Coppola, R.; Nazzaro, F. Ability of synbiotic encapsulated Saccharomyces cerevisiae boulardii to grow in berry juice and to survive under simulated gastrointestinal conditions. J. Microencapsul. 2014, 31, 299-305. [CrossRef]

81. Ivanovska, T.P.; Petrushevska-Tozi, L.; Grozdanov, A.; Petkovska, R.; Hadjieva, J.; Popovski, E.; Stafilov, T.; Mladenovska, K. From optimization of synbiotic microparticles prepared by spray-drying to development of new functional carrot juice. Chem. Ind. Chem. Eng. Q. 2014, 20, 549-564. [CrossRef]

82. Nualkaekul, S.; Cook, M.T.; Khutoryanskiy, V.V.; Charalampopoulos, D. Influence of encapsulation and coating materials on the survival of Lactobacillus plantarum and Bifidobacterium longum in fruit juices. Food Res. Int. 2013, 53, 304-311. [CrossRef]

83. Bhat, A.R.; Irorere, V.U.; Bartlett, T.; Hill, D.; Kedia, G.; Charalampopoulos, D.; Nualkaekul, S.; Radecka, I. Improving survival of probiotic bacteria using bacterial poly-gamma-glutamic acid. Int. J. Food Microbiol. 2015, 196, 24-31. [CrossRef]

84. Mortazavian, A.M.; Ehsani, M.R.; Azizi, A.; Razavi, S.H.; Mousavi, S.M.; Sohrabvandi, S.; Reinheimer, J.A. Viability of calcium-alginate-microencapsulated probiotic bacteria in Iranian yogurt drink (Doogh) during refrigerated storage and under simulated gastrointestinal conditions. Aust. J. Dairy Technol. 2008, 63, 25-30.

85. Gonzalez-Sanchez, F.; Azaola, A.; Gutierrez-Lopez, G.F.; Hernandez-Sanchez, H. Hernandez-Sanchez, H. Viability of microencapsulated Bifidobacterium animalis ssp. lactis BB12 in kefir during refrigerated storage. Int. J. Dairy Technol. 2010, 63, 431-436. [CrossRef]

86. Chaikham, P.; Apichartsrangkoon, A.; Worametrachanon, S.; Supraditareporn, W.; Chokiatirote, E.; Van der Wiele, T. Activities of free and encapsulated Lactobacillus acidophilus LA5 or Lactobacillus casei 01 in processed longan juices on exposure to simulated gastrointestinal tract. J. Sci. Food Agric. 2013, 93, 2229-2238. [CrossRef] [PubMed]

87. Praepanitchai, O.A.; Noomhorm, A.; Anal, A.K. Survival and Behavior of Encapsulated Probiotics (Lactobacillus plantarum) in Calcium-Alginate-Soy Protein Isolate-Based Hydrogel Beads in Different Processing Conditions (pH and Temperature) and in Pasteurized Mango Juice. BioMed. Res. Int. 2019, 2019, 9768152. [CrossRef] [PubMed]

88. Rodrigues, D.; Sousa, S.; Gomes, A.M.; Pintado, M.M.; Silva, J.P.; Costa, P.; Amaral, M.H.; Rocha-Santos, T.; Freitas, A.C. Storage stability of Lactobacillus paracasei as free cells or encapsulate in alginate-based microcapsules in low pH fruit juices. Food Bioprocess Technool. 2012, 5, 2748-2757. [CrossRef]

89. Krasaekoopt, W.; Watcharapoka, S. Effect of addition of inulin and galactooligosaccharide on the survival of microencapsulated probiotics in alginate beads coated with chitosan in simulated digestive system, yogurt and fruit juice. LWT Food Sci. Technol. 2014, 57, 761-766. [CrossRef]

90. Nualkaekul, S.; Lenton, D.; Cook, M.T.; Khutoryanskiy, V.V.; Charalampopoulos, D. Chitosan coated alginate beads for the survival of microencapsulated Lactobacillus plantarum in pomegranate juice. Carbohyd. Polym. 2012, 90, 1281-1287. [CrossRef]

91. McMaster, L.D.; Kokott, S.A.; Reid, S.J.; Abratt, V.R. Use of traditional African fermented beverages as delivery vehicles for Bifidobacterium lactis DSM 10140. Int. J. Food Microbiol. 2005, 102, 231-237. [CrossRef]

92. King, V.A.E.; Huang, H.Y.; Tsen, J.H. Fermentation of tomato juice by cell immobilized Lactobacillus acidophilus. MidTaiwan J. Med. 2007, 12, 1-7. 
93. Yadav, M.; Shukla, P. Efficient engineered probiotics using synthetic biology approaches: A review. Biotechnol. Appl. Biochem. 2019. in Press. [CrossRef]

94. Inda, M.E.; Broset, E.; Lu, T.K.; de la Fuente-Nunez, C. Emerging frontiers in microbiome engineering. Trends Immunol. 2019, 40, 952-973. [CrossRef]

95. Gholamhosseinpour, A.; Hashemi, S.M.B. Ultrasound pretreatment of fermented milk containing probiotic Lactobacillus plantarum AF1: Carbohydrate metabolism and antioxidant activity. J. Food Process. Eng. 2019, 42, e12930. [CrossRef]

96. Niamah, A.K. Ultrasound treatment (low frequency) effects on probiotic bacteria growth in fermented milk. J. Food Agric. Soc. 2019, 7, 103.

97. Costa, M.G.M.; Fonteles, T.V.; de Jesus, A.L.T.; Rodrigues, S. Sonicated pineapple juice as substrate for L. casei cultivation for probiotic beverage development: Process optimisation and product stability. Food Chem. 2013, 139, 261-266. [CrossRef] [PubMed]

98. Racioppo, A.; Corbo, M.R.; Piccoli, C.; Sinigaglia, M.; Speranza, B.; Bevilacqua, A. Ultrasound attenuation of lactobacilli and bifidobacteria: Effect on some technological and probiotic properties. Int. J. Food Microbiol. 2017, 243, 78-83. [CrossRef] [PubMed]

99. Patrignani, F.; Siroli, L.; Serrazanetti, D.I.; Lanciotti, R. Potential of High Pressure Homogenization and Functional Strains for the Development of Novel Functional Dairy Foods. In Technological Approaches for Novel Applications in Dairy Processing; Koca, N., Ed.; INTECH Publisher: Rijeka, Croatia, 2018; Volume 3, pp. 35-50.

100. Patrignani, F.; Iucci, L.; Lanciotti, R.; Vallicelli, M.; Maina Mathara, J.; Holzapfel, W.H.; Guerzoni, M.E. Effect of high pressure homogenization, not fat milk solids and milkfat on the technological performances of a functional strain for the production of probiotic fermented milks. J. Dairy Sci. 2009, 70, 4513-4523.

101. Zhang, C.; Yang, L.; Gu, R.; Ding, Z.; Guan, C.; Lu, M.; Gu, R. Mild heat stress limited the post-acidification caused by Lactobacillus rhamnosus hsryfm 1301 in fermented milk. Biotechnol. Lett. 2019, 41, 633-639. [CrossRef]

102. Derkx, P.M.F.; Janzern, T.; Sørensen, K.I.; Christensen, J.E.; Stuer lauridsen, B.; Johansen, E. The art of strain improvement of lactic acid bacteria without the use of recombinant DNA technology. Microb. Cell Fact. 2014, 13, S5. [CrossRef]

(C) 2020 by the authors. Licensee MDPI, Basel, Switzerland. This article is an open access article distributed under the terms and conditions of the Creative Commons Attribution (CC BY) license (http://creativecommons.org/licenses/by/4.0/). 